\title{
Antioxidant activity of methanol extract of cassava leaves (Manihot esculenta Crantz) using CUPRAC method
}

\section{Pengukuran aktivitas antioksidan ekstrak metanol daun singkong (Manihot esculenta Crantz) menggunakan metode CUPRAC}

\author{
Putri Indah Sayakti ${ }^{*}$, Norma Anisa ${ }^{1}$, Hafiz Ramadhan ${ }^{1}$ \\ ${ }^{1}$ Sekolah Tinggi Ilmu Kesehatan Borneo Lestari Banjarbaru, Kalimantan Selatan, Indonesia \\ *Corresponding author: putriindahsayakti@gmail.com
}

\begin{abstract}
Background: Antioxidants are a group of organic molecules and enzymes that work synergistically to enhance cellular defenses and combat oxidative stress. Antioxidants can come from plants because they contain many groups of phytochemical compounds and vitamins. One of the plants that has compounds with antioxidant activity is cassava.

Objective: To measure the antioxidant activity of methanol extract of cassava leaves using the CUPRAC method.

Methods: Cassava leaves were extracted by maceration using methanol as a solvent with the addition of $5 \%$ $\mathrm{H}_{2} \mathrm{SO}_{4}$. Phytochemical screening of flavonoids with $\mathrm{Mg}$ and $\mathrm{HCl}$, while phenol with the addition of $\mathrm{FeCl}_{3}$. The antioxidant activity based on the reaction of the test solution with CUPRAC reagent. Antioxidant activity can be determined by IC50 value by using $\mathrm{x}$ value as concentration and y value as absorbance.

Results: The results of phytochemical screening showed that the methanol extract of cassava leaves contained flavonoids and phenolic groups. The antioxidant capacity of the methanol extract of cassava leaves obtained an $\mathrm{IC}_{50}$ value of $156.03 \mathrm{ppm}$, while quercetin has a very strong capacity as an antioxidant with an $\mathrm{IC}_{50}$ of $9.83 \mathrm{ppm}$.

Conclusion: The methanol extract of cassava leaves has a weak antioxidant capacity in reducing metal ions. Keywords: Cassava leaves, Manihot esculenta Crantz, methanol extract, antioxidants, CUPRAC.

\section{Intisari}

Pendahuluan: Antioksidan adalah kelompok molekul organik dan enzim yang bekerja secara sinergis untuk meningkatkan pertahanan seluler dan memerangi stres oksidatif. Antioksidan dapat berasal dari tanaman karena banyak mengandung golongan senyawa fitokimia dan vitamin. Tanaman yang memiliki senyawa dengan aktivitas antioksidan salah satunya adalah singkong.

Tujuan: Mengukur aktivitas antioksidan dari ekstrak metanol daun singkong menggunakan metode CUPRAC. Metode: Daun Singkong diekstraksi secara maserasi menggunakan pelarut metanol dengan penambahan $\mathrm{H}_{2} \mathrm{SO}_{4} 5 \%$. Skrining fitokimia flavonoid dengan $\mathrm{Mg}$ dan $\mathrm{HCl}$, sedangkan fenol dengan penambahan $\mathrm{FeCl}_{3}$. Kapasitas antioksidan berdasarkan reaksi larutan uji dengan reagen CUPRAC yang diukur menggunakan spektrofotometer UV-Vis.

Hasil: Uji skrining fitokimia menunjukkan bahwa ekstrak metanol daun singkong mengandung senyawa golongan flavonoid dan fenolik. Kapasitas antioksidan ekstrak tersebut ditunjukkan dengan nilai IC $\mathrm{C}_{50}$ sebesar 156,03 ppm, sedangkan quersetin memiliki kapasitas yang sangat kuat sebagai antioksidan dengan IC $_{50}$ sebesar 9,83 ppm.

Kesimpulan: Aktivitas antioksidan ekstrak metanol daun singkong tergolong lemah dalam mereduksi ion logam.

Kata kunci: Daun singkong, Manihot esculenta Crantz, ekstrak metanol, antioksidan, CUPRAC
\end{abstract}


98 | Sayakti, P. I. dkk /Jurnal Ilmiah Farmasi (Scientific Journal of Pharmacy) Special Edition 2022, 97-106

\section{Pendahuluan}

Antioksidan merupakan senyawa penting dalam tubuh kita karena tugasnya menghambat molekul radikal bebas. Radikal bebas merupakan senyawa sangat reaktif akibat adanya elektron yang tidak berpasangan pada kulit terluar sehingga menyebabkan terjadinya reaksi berantai yang terjadi secara terus menerus. Reaksi ini mengambil elektron yang terdapat pada sel normal untuk menstabilkan reaksi berantai dan mengakibatkan kerusakan pada sel normal. Antioksidan dapat menghentikan reaksi ini dengan meredamkan terjadinya reaksi berantai (Wahdaningsih et al., 2011). Mekanisme peredaman yang dilakukan oleh antioksidan adalah dengan memberikan elektron kepada radikal bebas sehingga elektron terluarnya menjadi berpasangan dan lebih stabil. Peredaman ini menghambat reaksi berantai sehingga menghentikan dan mencegah kerusakan yang terjadi pada sel normal. Senyawa antioksidan dapat bersumber dari bahan alam, salah satunya adalah simplisia daun singkong (Hasim et al., 2016).

Berdasarkan hasil penelitian Hasim et al., (2016) ekstrak metanol daun singkong mengandung saponin, tanin, fenolik, alkaloid, dan flavonoid, dengan nilai total fenolik dan flavonoid yang paling dominan sehingga kedua senyawa inilah yang diduga berpotensi sebagai antioksidan. Kedua senyawa tersebut diketahui mampu memberikan elektron dan diikatkan pada elektron pada kulit terluar radikal bebas sehingga radikal bebas menjadi stabil dan tidak lagi mengganggu sel normal (Faezah et al., 2013). Penelitian tersebut juga melakukan uji aktivitas antioksidan dengan metode DPPH dan nilai $\mathrm{IC}_{50}$ yang didapatkan sebesar 92,10 mg/L, nilai ini menunjukkan aktivitas antioksidan ekstrak tergolong kuat. Salah satu senyawa flavonoid yang beraktivitas sebagai antioksidan dalam daun singkong adalah rutin (Tsumbu et al., 2011). Selain itu, menurut penelitian lain yang dilakukan oleh Yura et al., (2016) menggunakan ekstrak dan metode yang sama menghasilkan aktivitas yang lebih tinggi dengan $\mathrm{IC}_{50}$ sebesar $16,06 \mu \mathrm{g} / \mathrm{ml}$.

Salah satu metode pengujian antioksidan adalah metode CUPRAC. Pada metode ini, reagen yang digunakan adalah $\mathrm{Cu}(\mathrm{II})-$ neokuproin (Cu(II)-(Nc)2) untuk mengoksidasi kromogenik sehingga dapat dilakukan pengukuran reduksi ion $\mathrm{Cu}(\mathrm{II})$. Metode ini banyak digunakan karena reagen yang digunakan berupa CUPRAC yang bersifat selektif dengan nilai potensial reduksi yang rendah sehingga mudah untuk dilakukan dan berbiaya rendah (Maryam et al., 2016). Berdasarkan latar belakang nilai IC $_{50}$ ekstrak metanol daun singkong yang kuat, yaitu 92,10 mg/L dan 16,06 $\mu \mathrm{g} / \mathrm{mL}$ dengan metode DPPH, maka perlu dilakukan perhitungan antioksidan dengan metode CUPRAC. Pengujian aktivitas antioksidan dengan metode CUPRAC belum dilakukan sebelumnya untuk ekstrak metanol daun singkong. Oleh karenanya, dilakukan uji antioksidan ekstrak metanol daun singkong dengan metode CUPRAC. 


\section{Metode}

2.1 Alat

Alat pada penelitian adalah alat gelas $\left(\right.$ Pyrex $^{\circledR}$ ), neraca analitik (Fujitsu ${ }^{\circledR}$ ), mikropipet (Dragon Lab ${ }^{\circledR}$ ), seperangkat alat rotary evaporator (IKFR 10 ${ }^{\circledR}$ ), seperangkat alat maserasi, waterbath (Memmert $\left.{ }^{\circledR}\right)$ dan spektrofotometer UV-Vis (PG Instruments-T60 ${ }^{\circledR}$ ).

\subsection{Bahan}

Bahan untuk penelitian ini berupa daun singkong, aluminium foil, aquadest, ammonium asetat $\left(\operatorname{Merck}^{\circledR}\right)$, asam sulfat $\left(\operatorname{Merck}^{\circledR}\right), \mathrm{CuCl}_{2} \cdot 2 \mathrm{H}_{2} \mathrm{O}$ (Merck $\left.{ }^{\circledR}\right)$, etanol p.a $\left(\right.$ Bratachem $\left.^{\circledR}\right), \mathrm{FeCl}_{3}$ $\left(\right.$ Merck $\left.^{\circledR}\right), \mathrm{HCl}\left(\right.$ Merck $\left.^{\circledR}\right)$, kuersetin (Sigma aldrich $\left.{ }^{\circledR}\right)$, metanol teknis (Bratachem ${ }^{\circledR}$ ) , Neocuproine $\left(\operatorname{Merck}^{\circledR}\right)$ dan serbuk Magnesium $\left(\operatorname{Merck}^{\circledR}\right)$.

\subsection{Pengambilan sampel daun singkong}

Sampel dikumpulkan pada bulan Januari 2019 dari kota Banjarbaru, Kalimantan Selatan dan dideterminasi di Laboratorium Dasar Fakultas Matematika dan Ilmu Pengetahuan Alam (FMIPA) Universitas Lambung Mangkurat. Bagian tanaman yang digunakan untuk penelitian ini adalah daun yang matang, yaitu daun yang terdapat pada posisi ke 4 - 7 dari pucuk tanaman dengan usia 6 bulan (Hasim et al., 2016).

\subsection{Pembuatan simplisia daun singkong}

Sampel yang telah dikumpulkan disortasi basah, yaitu dipisahkan dari jenis daun lain ataupun pengotor yang ikut terbawa. Selanjutnya daun dicuci di bawah air mengalir, ditimbang, dirajang dan dikeringkan dengan sinar matahari secara tidak langsung memakai kain hitam. Sortasi kering kemudian dilakukan setelah semua bagian daun telah menjadi kering sempurna dan kemudian dilanjutkan proses penyerbukan. Serbuk yang dihasilkan diayak hingga halus dengan pengayakan mesh 100, lalu serbuk ditimbang, dan dicatat beratnya dilanjutkan dengan penyimpanan di wadah yang tertutup baik (Hasim et al., 2016).

\subsection{Pembuatan ekstrak metanol daun singkong}

Ekstraksi menggunakan maserasi dengan pelarut metanol. Awalnya, serbuk simplisia sebanyak 150 gram dimaserasi dalam $750 \mathrm{~mL}$ pelarut metanol dengan perbandingan (1:5) dan ditambahkan asam sulfat 5\%. Maserasi dilakukan selama 24 jam dengan pengadukan beberapa kali lalu disaring dengan kertas saring dan remaserasi sebanyak 3 kali. Filtrat yang didapatkan selanjutnya dipekatkan dengan rotary evaporator pada suhu $50-60^{\circ} \mathrm{C}$ hingga menjadi ekstrak kental (Hasim et al., 2016).

\subsection{Skrining fitokimia}

\subsubsection{Identifikasi flavonoid}


Identifikasi flavonoid dilakukan dengan mencampurkan 0,5 gram ekstrak kental dengan 2 mL metanol kemudian ditambahkan serbuk Mg sebanyak 2 mg dan diberikan 3 tetes $\mathrm{HCl}$ pekat lalu dikocok kuat. Warna merah, kuning atau jingga yang terbentuk menunjukkan sampel positif flavonoid (Purwati et al., 2017) .

\subsubsection{Identifikasi fenol}

Identifikasi fenol diawali dengan melarutkan 0,5 gram ekstrak kental pada $2 \mathrm{~mL}$ metanol. Larutan kemudian ditambah 3 tetes larutan $\mathrm{FeCl}_{3}$ hingga terbentuk warna hitam hijau kebiruan. Apabila warna tersebut tidak terbentuk maka sampel negatif fenol (Tiwari et al., 2011).

\subsection{Pengujian antioksian secara kuantitatif dengan metode CUPRAC}

\subsubsection{Pembuatan larutan untuk pengujian CUPRAC}

Larutan $\mathrm{CuCl}_{2}$ dibuat dengan menimbang 0,4262 gram $\mathrm{CuCl}_{2} \cdot 2 \mathrm{H}_{2} \mathrm{O}$ yang kemudian dimasukkan ke dalam labu ukur $250 \mathrm{~mL}$. Serbuk kemudian dilarutkan dengan air sampai tanda batas. Buffer yang digunakan adalah amonium asetat pH 7 yang dibuat dengan melarutkan 19,27 gram NH4Ac pada labu ukur $250 \mathrm{~mL}$ dan ditambah akuades sampai tanda. Larutan Neocuproine (Nc) juga dibuat dengan melarutkan 0,039 gram pada labu ukur ukuran $25 \mathrm{~mL}$ Nc dan diencerkan sampai tanda menggunakan etanol p.a (Maryam et al., 2016).

\subsubsection{Penentuan panjang gelombang maksimum}

Penentuan panjang gelombang dilakukan dengan menambahkan larutan $0.01 \mathrm{M} \mathrm{CuCl}_{2} .2 \mathrm{H}_{2} \mathrm{O}$, 0,0075 M Nc, $1 \mathrm{M}$ bufer amonium asetat, etanol p.a masing-masing $1 \mathrm{dan}$ 0,1 $\mathrm{mL}$ akuades dalam vial. Larutan kemudian diukur absorbansi pada panjang gelombang 400-800 nm menggunakan spektrofotometer UV-Vis (Haeria, 2013).

\subsubsection{Pembuatan dan pembacaan absorbansi larutan blanko}

Larutan blanko Larutan $0.01 \mathrm{M} \mathrm{CuCl} 2.2 \mathrm{H} 2 \mathrm{O}, 0,0075 \mathrm{M} \mathrm{Nc}, 1 \mathrm{M}$ bufer amonium asetat, etanol p.a masing-masing diambil $1 \mathrm{~mL}$ untuk dimasukkan pada vial dan ditambah 0,1 mL akuades. Vial selanjutnya diinkubasi dalam ruangan gelap selama 30 menit. Larutan CUPRAC yang sudah jadi ini dituangkan kedalam kuvet dan dibaca serapan maksimumnya pada spektrofotometer UV-Vis dengan panjang gelombang maksimum yang didapat pada langkah 2.7.2. (Haeria, 2013).

\subsubsection{Pembuatan dan pembacaan larutan kurva baku pembanding kuersetin}

Larutan stok kuersetin 1000 ppm dibuat dengan menimbang 25 mg kuesertin yang dimasukan ke labu ukur 25 mL. Etanol p.a kemudaian ditambahkan sampai tanda batas. Larutan stok ini selanjutnya diencerkan menjadi 100 ppm dengan cara mengambil larutan stok sebanyak 2,5 mL yang diencerkan dengan etanol p.a sampai tanda batas pada labu ukur 25 mL. Larutan kurva baku 1, 2, 3, 4, dan 5 ppm kemudian dibuat dengan memipet larutan kuersetin 100 ppm sebanyak 
0,$25 ; 0,5 ; 0,75 ; 1 \mathrm{~mL}$ dan $1,25 \mathrm{~mL}$ untuk dimasukkan ke dalam labu ukur $25 \mathrm{~mL}$ yang terpisah. Masing-masing labu ukur ditambahkan etanol p.a hingga tanda batas (Haeria, 2013).

Pembacaan absorbansi dilakukan dengan mengambil sebanyak $1 \mathrm{~mL}$ setiap seri larutan kuersetin dan dimasukan ke dalam vial. Semua vial ditambah $1 \mathrm{ml}$ larutan $0.01 \mathrm{M} \mathrm{CuCl} 2.2 \mathrm{H} 2 \mathrm{O}, 1 \mathrm{~mL}$ 0,0075 M Nc, $1 \mathrm{~mL} 1 \mathrm{M}$ bufer amonium asetat dan 0,1 mL akuades. Vial kemudian diinkubasi di ruang gelap selama 30 menit. Selanjutnya, larutan ini dituang ke dalam kuvet dan diukur serapanya pada spektrofotometer UV-Vis dengan panjang gelombang maksimum yang didapat pada langkah sebelumnya (Haeria, 2013).

\subsubsection{Pembuatan larutan uji ekstrak metanol daun singkong}

Larutan uji dibuat dengan melarutkan 50 mg ekstrak metanol pada etanol p.a dalam labu ukur $50 \mathrm{~mL}$ sehingga diperoleh konsentrasi 1000 ppm (larutan stok). Larutan induk ini kemudian diambil 1,5; 3; 6; 12; dan $24 \mathrm{~mL}$ sehingga diperoleh konsentrasi 10, 30, 60, 120, dan 180 ppm sebanyak $50 \mathrm{~mL}$ (Haeria, 2013). Masing-masing konsentrasi larutan uji sebanyak $1 \mathrm{~mL}$ kemudian dimasukkan kedalam vial dan ditambah $1 \mathrm{~mL}$ larutan $\mathrm{CuCl} 2.2 \mathrm{H} 200.01 \mathrm{M}, 1 \mathrm{~mL}$ Nc 0,0075 M, $1 \mathrm{~mL}$ buffer amonium asetat $1 \mathrm{M}$ dan 0,1 $\mathrm{mL}$ akuades. Inkubasi dan pengukuran absorbansi sampel selanjutnya dilakukan dengan cara seperti pada larutan kurva baku kuersetin (Haeria, 2013).

\section{Hasil dan pembahasan}

Determinasi dilakukan sebagai langkah awal pada suatu penelitian untuk mengetahui kebenaran indentitas tanaman yang akan digunakan sehingga tidak terjadi kesalahan penggunaan sampel. Hasil determinasi pada penelitian ini menyebutkan bahwa tanaman benar merupakan tanaman singkong dengan nama latin Manihot esculenta Crantz. Ekstrak daun singkong didapatkan dari hasil maserasi serbuk simplisia menggunakan pelarut metanol. Metode maserasi dipilih karena sederhana dan sesuai digunakan untuk simplisia yang tidak keras selain itu juga keuntungan metode maserasi adalah kerusakan pada komponen kimia sangat minimal serta cocok digunakan pada zat yang tahan panas. Maserasi dilakukan dengan dua kali remaserasi bertujuan untuk mengoptimalkan penyarian. Selama proses ekstraksi maserasi terjadi interaksi antara zat terlarut dengan pelarut, hal ini akan mendorong keluarnya zat aktif yang berada dalam sel menuju keluar sel dan terlarut dalam pelarut yang digunakan. Perpindahan ini disebut sebagai difusi yang terjadi akibat perbedaan konsentrasi zat aktif yang terdapat di luar dan di dalam sel, dan akan berulang sampai terjadinya keseimbangan (Wahyulianingsih et al., 2016).

Maserasi dilakukan dengan merendam 150 gram serbuk simplisia daun singkong dalam 750 mL metanol sebagai cairan penyari dengan perbandingan (1:5) dan ditambahkan pelarut asam sulfat 
5\% sebanyak 0,6 ml setiap 1 kali maserasi. Pelarut metanol digunakan sebagai penyari

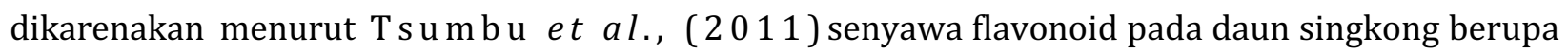
rutin yang menggandung satu glikosida (monoglikosida). Monoglikosida ini mengakibatkan senyawa rutin lebih larut dalam metanol sedangkan pelarut asam sulfat 5\% ditambahkan agar mampu menghidrolisis senyawa rutin menjadi kuersetin murni (Karimova et al., 2016). Penelitian Hasim et al., (2016) juga menyatakan bahwa senyawa-senyawa aktif dalam daun singkong lebih banyak terekstrak menggunakan pelarut metanol dengan metode ekstraksi maserasi dibandingkan dengan metode ekstraksi infundasi menggunakan pelarut air yaitu dapat dilihat dari hasil rendemen ekstrak metanol (1,03 dan 5,56 \%) dan ekstrak air (0,89 dan 3,73 \%).

Ekstrak yang diperoleh kemudian dipekatkan menjadi ekstrak kental dengan cara menguapkan pelarut sampai ekstrak menjadi kental menggunakan rotary evaporator dan waterbath. Proses rotary evaporator dan waterbath yang dilakukan pada suhu dibawah titik didih metanol $64,7^{\circ} \mathrm{C}$. Suhu yang digunakan adalah $50-60^{\circ} \mathrm{C}$ dikarenakan untuk meningkatkan proses pengguapan pelarut dan diharapkan tidak merusak senyawa antioksidan pada ekstrak (Hasim et al., 2016). Tujuan pemekatan ekstrak menggunakan alat rotary evaporator dan waterbath untuk menghilangkan pelarut sehingga didapatkan bobot tetap dan nilai \% randemen ekstrak daun singkong seperti pada Tabel 2.

Tabel 2. Randemen Ekstrak Daun Singkong (Manihot esculenta Crantz)

\begin{tabular}{lccc}
\hline Pelarut & $\begin{array}{c}\text { Bobot Simplisia } \\
\text { Diekstraksi (g) }\end{array}$ & $\begin{array}{c}\text { Bobot Ekstrak Kental } \\
\text { (g) }\end{array}$ & $\begin{array}{c}\text { Rendemen } \\
\text { (\%) }\end{array}$ \\
\hline Metanol & 150 & 39,7615 & 26,5076 \\
\hline
\end{tabular}

Skrining fitokimia selanjutnya dilakukan untuk mengindentifikasi kandungan atau komponen yang terdapat dalam ekstrak tumbuhan. Menurut Faezah et al. (2013), tumbuhan yang berpotensi memiliki fungsi antioksidan adalah daun singkong dengan kandungan senyawa utama berupa flavonoid dan fenolik sehingga pada uji skrining yang dilakukan adalah uji flavonoid dan fenol. Hasil uji fitokimia dapat diperlihatkan pada Tabel 3.

Pada hasil pengujian skrining fitokimia yang dilakukan pada uji identifikasi flavonoid dan fenolik, hasil yang diperoleh menunjukan hasil positif adanya kandungan senyawa flavonoid dan fenolik yang dapat dilihat adanya perubahan warna seperti yang dituliskan oleh Purwati., et al (2017). Perubahan warna menjadi merah, kuning atau jingga memperlihatkan adanya flavonoid sedangkan warna hitam hijau kebiruan merupakan indikator adanya senyawa fenol (Tiwari et al., 2011). Hasil identifikasi flavonoid dengan prinsip reaksi oksidasi reduksi ini menujukan hasil positif. Perubahan warna terjadi karena senyawa flavonoid akan direduksi oleh hasil reaksi $\mathrm{HCl}$ dan Mg akan membentuk senyawa komplek berwarna kuning merah, dan jingga. Skema reaksi rutin 
dengan $\mathrm{HCl} \& \mathrm{Mg}$ diperlihatkan pada Gambar 1.

Tabel.3 Hasil uji skrining fitokimia ekstrak metanol daun singkong (M. esculenta Crantz)

\begin{tabular}{cccc}
\hline Uji & Pereaksi & Hasil & Keterangan \\
\hline Flavonoid & $\begin{array}{c}\text { metanol }+ \text { serbuk Mg } 2 \mathrm{mg}+3 \\
\text { tetes } \mathrm{HCl}\end{array}$ & Perubahan kuning & Positif \\
Fenol & metanol +3 tetes FeCl3 & $\begin{array}{c}\text { Terbentuknya warna hitam } \\
\text { hijau kebiruan }\end{array}$ & Positif \\
\hline
\end{tabular}

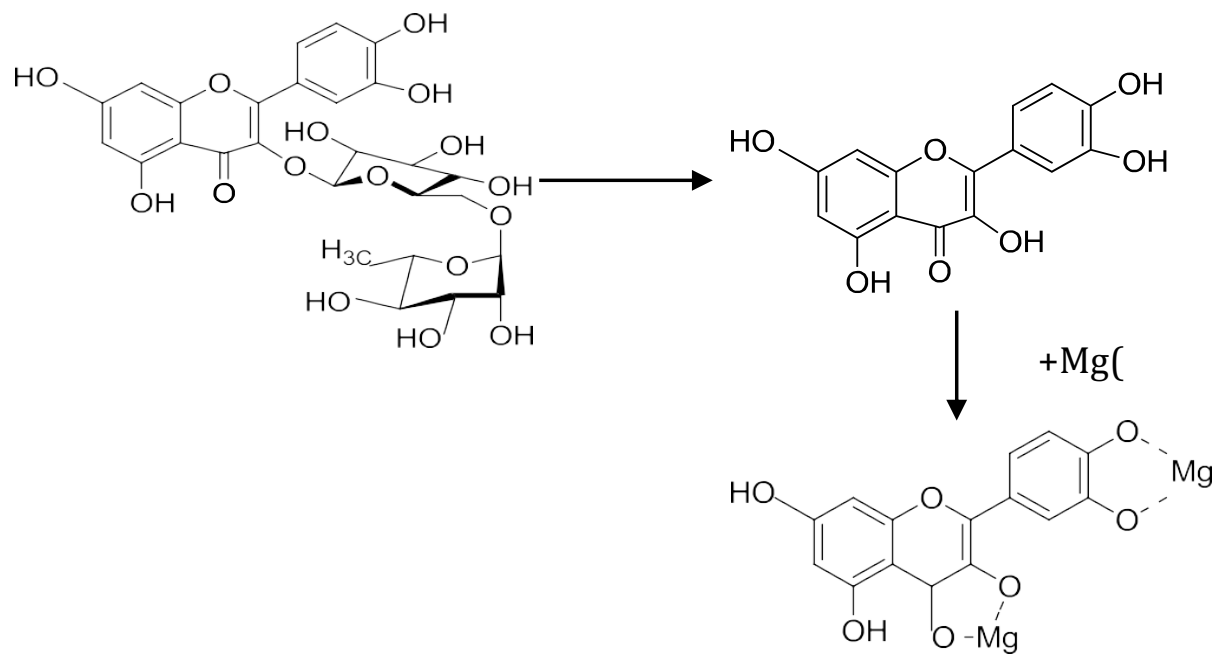

Gambar 1. Skema reaksi rutin dengan $\mathrm{HCl} \& \mathrm{Mg}$<smiles>CP(Oc1cc(C(=O)O)cc(O)c1O)Oc1c(O)cc(C(=O)O)cc1O</smiles>

Gambar 2. Skema reaksi fenolik dengan $\mathrm{FeCl}^{3}$

Pada hasil pengujian fenol pada penelitian ini menunjukkan positif, yaitu dengan terbentuknya warna biru kehitaman akibat fenol yang dapat mereduksi $\mathrm{Fe}^{3+}$ menjadi $\mathrm{Fe}^{2+}$ (besi(III) heksasianoferterat)(Nugrahani, 2015). Skema reaksi fenolik dengan $\mathrm{FeCl}_{3}$ diperlihatkan pada Gambar 2. Senyawa fenolik dan juga flavonoid merupakan salah satu metabolit sekunder dengan fungsi 
sebagai antioksidan yang terdapat dalam daun singkong. Kedua senyawa ini dapat membantu meredamkan atau menghambat aktivitas senyawa radikal bebas yang ditemukan dalam tubuh dengan mekanisme donor elektron sehingga elektron pada orbital terluar pada radikal bebas menjadi stabil (Faezah et al., 2013). Metode CUPRAC dapat digunakan untuk melihat aktivitas antioksidan dan mengukur kemampuan antioksidan pada suatu sampel. Kelebihan metode CUPRAC adalah sederhana, reaksi mengoksidasi antioksidan terjadi dengan cepat, reagen lebih stabil dan dapat mengukur senyawa hidrofilik dan lipofilik (Maryam et al., 2016).

Pada pengujian aktivitas antioksidan menggunakan metode CUPRAC reagen yang digunakan adalah neocuproin (Nc) yang berlaku sebagai agen pengoksidasi kromogenik dan akan membentuk senyawa kelat dengan $\mathrm{Cu}^{2+}$ menyebabkan terbentuknya reduksi ion $\mathrm{Cu}^{2+}-\mathrm{Nc}$ yang berwarna biru. Aktivitas antioksidan dapat diukur dari kemampuan $\mathrm{Cu}^{2+} \mathrm{Nc}$ menjadi $\mathrm{Cu}^{+}-\mathrm{Nc}$ yang ditandai terbentuknya warna kuning. Khelat $\mathrm{Cu}^{+}-\mathrm{Nc}$ yang terbentuk ini stabil karena tidak mudah berubah akibat adanya perubahan lingkungan seperti udara, cahaya, ataupun pH. Perubahan warna inilah menyebabkan terjadinya perubahan nilai absorbansi akibat perubahan jumlah cahaya yang dapat diserap ketika diukur menggunakan spektrofotometer UV-Vis (Maryam et al., 2016).

Tabel 3. Hasil uji aktivitas antioksidan kuersetin

\begin{tabular}{ccccccc}
\hline $\begin{array}{c}\text { Konsentrasi } \\
\text { (ppm) }\end{array}$ & $\begin{array}{c}\text { Abs } \\
\text { Blanko }\end{array}$ & $\begin{array}{c}\text { Rata -rata } \\
\text { Absorbansi }\end{array}$ & $\begin{array}{c}\text { Rata -rata } \\
\text { Inhibisi }\end{array}$ & SD & $\begin{array}{c}\text { Persamaan } \\
\text { regresi }\end{array}$ & $\begin{array}{c}\mathrm{IC}_{50} \\
\text { (ppm) }\end{array}$ \\
\hline 1 & 0,801 & 0,693 & 13,44 & 0,97 & $\mathrm{y}=4,1615 \mathrm{x}$ & 9,87 \\
2 & 0,801 & 0,664 & 17,35 & 0,31 & $+8,9221$ & \\
3 & 0,801 & 0,633 & 20,47 & 0,38 & $\mathrm{R}^{2}=0,9969$ & \\
4 & 0,801 & 0,594 & 26,59 & 0,90 & & \\
5 & 0,801 & 0,562 & 30,58 & 0,75 & & \\
\hline
\end{tabular}

Hasil pengukuran aktivitas antioksidan digambarkan dengan nilai $\mathrm{IC}_{50}$ yaitu konsentrasi yang menyebabkan hilangnya konsentrasi awal sebesar 50\%. Aktivitas antioksidan yang semakin baik akan ditunjukkan dengan semakin kecilnya nilai IC $_{50}$ (Nugraha et al., 2017). Pengujian aktivitas antioksidan secara kuantitatif menggunakan kontrol positif kuersetin dan ekstrak metanol daun singkong. Langkah pertama yang dilakukan adalah mencari panjang gelombang maksimum CUPRAC dan didapatkan nilai sebesar $450 \mathrm{~nm}$. Panjang gelombang ini menunjukkan panjang gelombang yang memberikan serapan paling maksimal dan menunjukkan nilai kepekaan paling besar. Pengujian kuersertin dan ekstrak dilakukan dengan berbagai seri konsentrasi yang telah dilarutkan menggunakan larutan CUPRAC yang kemudian dibaca absorbansinya dengan menggunakan spektrofotometer UV-Vis. Nilai aktivitas antioksidan kuersetin dapat diketahui dari Tabel 3.

Berdasarkan hasil uji antioksidan kuersetin dan ekstrak metanol daun singkong secara kuantitatif diperoleh menggunakan Microsoft Excel 2010 untuk menghasilkan nilai persamaan 
regresi linier yang dapat digunakan untuk menghitung nilai $\mathrm{IC}_{50}$. Nilai tersebut adalah konsentrasi yang dibutuhkan untuk mendapatkan aktivitas 50\%. Perhitungan nilai $\mathrm{IC}_{50}$ dilakukan menggunakan data persen inhibisi yang digunakan untuk mendapatkan persamaan regresi linier $\mathrm{y}=\mathrm{bx}+\mathrm{a}$ dengan konsentrasi sampel adalah $\mathrm{x}$ dan persen inhibisi sebagai $\mathrm{y}$. Nilai $\mathrm{IC}_{50}$ dihitung dengan mengganti nilai y sebesar 50 untuk mendapatkan nilai x. Semakin rendah nilai $\mathrm{IC}_{50}$ yang didapatkan maka semakin baik aktivitas antioksidannya (Nugraha et al., 2017). Hasil uji antioksidan ekstrak metanol daun singkong dapat dilihat pada Tabel 4.

Tabel 4. Hasil uji aktivitas antioksidan ekstrak metanol daun singkong

\begin{tabular}{ccccccc}
\hline $\begin{array}{c}\text { Konsentrasi } \\
\text { (ppm) }\end{array}$ & $\begin{array}{c}\text { Abs } \\
\text { Blanko }\end{array}$ & $\begin{array}{c}\text { Rata -rata } \\
\text { Absorbansi }\end{array}$ & $\begin{array}{c}\text { Rata - rata } \\
\text { \% Inhibisi }\end{array}$ & SD & $\begin{array}{c}\text { Persamaan } \\
\text { kurva baku }\end{array}$ & $\begin{array}{c}\text { IC50 } \\
\text { (ppm) }\end{array}$ \\
\hline 10 & 0,797 & 0,761 & 4,48 & 2,70 & $\mathrm{y}=0,2607 \mathrm{x}$ & 154,54 \\
30 & 0,797 & 0,620 & 22,21 & 0,38 & $+9,7097$ & \\
60 & 0,797 & 0,566 & 29,74 & 1,15 & & \\
120 & 0,797 & 0,456 & 42,74 & 0,38 & & \\
180 & 0,797 & 0,369 & 53,66 & 0,32 & & \\
\hline
\end{tabular}

Pengujian antioksidan pada kuersetin diperoleh hasil sebesar 9,87 ppm dan ekstrak metanol daun singkong sebesar 154,54 ppm. Berdasarkan hasil yang didapatkan kemampuan antioksidan ekstrak metanol daun singkong lebih rendah dibandingkan kuersetin dikarenakan kuersetin merupakan senyawa flavonol (golongan flavonoid terbesar) yang memiliki potensi biologis besar dalam tubuh dalam menangkal radikal bebas sedangkan ekstak metanol daun singkong merupakan senyawa campuran senyawa metabolit sekunder yang dihasilkan oleh tanaman yang saling berinteraksi untuk menimbulkan aktivitas tertentu (Faezah et al., 2013). Perbedaan nilai $\mathrm{IC}_{50}$ juga bisa disebabkan karena adanya kemungkinan senyawa lain yang larut dalam cairan penyari yang tidak berkhasiat sebagai antioksidan sehingga dapat menggangu peredaman radikal bebas CUPRAC. Menurut Borges et al., (2013), beberapa faktor eksternal seperti dapat mempengaruhi komponen senyawa dan konsentrasinya, termasuk komponen fenol dan flavonoid.

\section{Kesimpulan}

Aktivitas antioksidan ekstrak metanol daun singkong terkategorisasi lemah dengan nilai $\mathrm{IC}_{50}$ sebesar 154,54 ppm yang diukur menggunakan metode CUPRAC.

\section{Ucapan terimakasih}

Terima kasih kepada STIKES Borneo Lestari atas penyediaan fasilitas laboratorium. 


\section{Daftar pustaka}

Borges, L., Alves, S., Leite Sampaio, B., Conceição, E., Bara, M., \& Paula, J. (2013). Environmental Factors Affecting the Concentration of Phenolic Compounds in Myrcia tomentosa Leaves. Brazkilian Journal of Pharmacognosy, 23(2), 230-238. doi:10.1590/S0102695X2013005000019

Faezah, O. N., Aishah, H. S., \& Kalsom, Y. U. (2013). Comparative Evaluation of Organic and Inorganic Fertilizers on Total Phenolic, Total Flavonoid, Antioxidant Activity and Cyanogenic Glycosides in Cassava (Manihot esculenta). African Journal of Biotechnology, 12(18), 24142421.

Haeria, H. (2013). Penetapan Kadar Flavanoid Total dan Uji Daya Antioksidan Ekstrak Etanol Daun Unggu (Graftophylum pictum L.) Griff). , Alauddin Makasar. Vol.1; No.1. Jurnal Farmasi FIK Alauddin Makasar, 1(1). doi:https://doi.org/10.24252/jurfar.v1i1.2088

Hasim, H., Falah, S., \& Dewi, L. K. (2016). Effect of Boiled Cassava Leaves ( Manihot esculenta Crantz) on Total Phenolic, Flavonoid and its Antioxidant Activity, Institut Pertanian Bogor.

Karimova, E. R., Baltina, L. A., \& Abdullin, M. I. (2016). Production of Quercetin by Acid Hydrolisis of Rutin. Vestnik Bashkirskogo Universiteta 21(1), 78-80.

Maryam, S. M., Pratama, R. Y., Effendi, N., \& Naid, T. (2016). Analisis Aktivitas Antioksidan Ekstrak Etanolik Daun Yodium (Jatropha multifidi L.) dengan Metode Cuprac Ion Reducing Antioxidant Capacity (CUPRAC). Jurnal Fitofarmaka Indonesia 2(1).

Nugraha, A. T., Firmansyah, M. S., \& Jumaryatno, P. (2017). Profil Senyawa dan Aktifitas Antioksidan Daun Yakon (Smallanthus sonchifolius) dengan Metode DPPH dan Cuprac. Jurnal Ilmiah Farmasi 13(1), 14-20.

Nugrahani, R. (2015). Analisis Potensi Serbuk Ekstrak Buncis (Phaseolus vulgaris L.) sebagai Antioksidan. (Magister). Universitas Mataram,

Purwati, S., Lumowa, S. V. T., \& Samsurianto, S. (2017). Skrining Fitokimia Daun Saliara (Lantana Camara L) sebagai Peptisida Nabati Penekan Hama dan Insiedensi Penyakit pada Tanaman Hotilkultura di Kalimantan Timur. Paper presented at the Prosiding Seminar Kimia, FMIPA Unmul.

Tiwari, P., Kaur, M., \& Kaur, H. (2011). Phytochemical Screening and Extraction: A Review. Journal Internationale Pharmaceutical Sciencia, 1, 103-104.

Tsumbu, C. N., Deby-Dupont, G., Tits, M., Angenot, L., Franck, T., Serteyn, D., \& Mouithys-Mickalad, A. (2011). Antioxidant and antiradical actitivities of Manihot esculenta Cranz (Euphohorbiaceae) Leaves and Other Selected Tropical Gree Vegetables Investigied on Lipopperoxidation and Phorbol-12- Myristate-13-Actate (PMA) Activated Monocytes. Nutrients, 3(9), 818-838. doi:10.3390/nu3090818

Wahdaningsih, S., Setyowati, E. P., \& Wahyuono, S. (2011). Aktivitas Penangkap Radikal Bebas dari Batang Pakis (Alsophila glauca J. Sm). Majalah Obat Tradisional, 16(3), 156-160.

Wahyulianingsih, W., Handayani, S., \& Malik, A. (2016). Penetapan kadar Flavonoid Total Ekstrak Daun Cengkeh (Syzygium aromaticum (L.) Merr dan Perry). Jurnal Fitofarmaka Indonesia,, 3, 189. doi:https://doi.org/10.33096/jffi.v3i2.221

Yura, S., M.I., S., \& Novita, M. (2016). Pengaruh Jenis Pelarut Terhadap Aktivitas Antioksidan dan Kandungan Fenol Beberapa Jenis Bayam dan Sayuran Lain. Jurnal Ilmiah Mahasiswa Pertanian, 1(1). doi:https://doi.org/10.17969/jimfp.v1i1.900 